\title{
Thyroid Hormone Status Interferes with Estrogen Target Gene Expression in Breast Cancer Samples in Menopausal Women
}

\author{
Sandro José Conde, ${ }^{1,2}$ Renata de Azevedo Melo Luvizotto, ${ }^{2}$ \\ Maria Teresa de Síbio, ${ }^{2}$ and Célia Regina Nogueira ${ }^{2}$ \\ ${ }^{1}$ Department of Biological Science, São Paulo Federal Institute (IFSP), 18136-540 São Roque, SP, Brazil \\ ${ }^{2}$ Department of Internal Medicine, Division of Endocrinology and Metabolism, UNESP, 18618-000 Botucatu, SP, Brazil \\ Correspondence should be addressed to Sandro José Conde; condesan@yahoo.com.br
}

Received 11 November 2013; Accepted 11 January 2014; Published 20 February 2014

Academic Editors: J. Pachucki, V. Pezzi, and D. F. Skafar

Copyright ( 12014 Sandro José Conde et al. This is an open access article distributed under the Creative Commons Attribution License, which permits unrestricted use, distribution, and reproduction in any medium, provided the original work is properly cited.

\begin{abstract}
We investigated thyroid hormone levels in menopausal $\mathrm{BrC}$ patients and verified the action of triiodothyronine on genes regulated by estrogen and by triiodothyronine itself in $\mathrm{BrC}$ tissues. We selected 15 postmenopausal $\mathrm{BrC}$ patients and a control group of 18 postmenopausal women without BrC. We measured serum TPO-AB, TSH, FT4, and estradiol, before and after surgery, and used immunohistochemistry to examine estrogen and progesterone receptors. BrC primary tissue cultures received the following treatments: ethanol, triiodothyronine, triiodothyronine plus 4-hydroxytamoxifen, 4-hydroxytamoxifen, estrogen, or estrogen plus 4-hydroxytamoxifen. Genes regulated by estrogen (TGFA, TGFB1, and PGR) and by triiodothyronine (TNFRSF9, BMP-6, and THRA) in vitro were evaluated. TSH levels in BrC patients did not differ from those of the control group (1.34 \pm 0.60 versus 2.41 $\pm 1.10 \mu \mathrm{U} / \mathrm{mL}$ ), but FT4 levels of BrC patients were statistically higher than controls ( $1.78 \pm 0.20$ versus $0.95 \pm 0.16 \mathrm{ng} / \mathrm{dL})$. TGFA was upregulated and downregulated after estrogen and triiodothyronine treatment, respectively. Triiodothyronine increased PGR expression; however 4-hydroxytamoxifen did not block triiodothyronine action on PGR expression. 4-Hydroxytamoxifen, alone or associated with triiodothyronine, modulated gene expression of TNFRSF9, BMP-6, and THRA, similar to triiodothyronine treatment. Thus, our work highlights the importance of thyroid hormone status evaluation and its ability to interfere with estrogen target gene expression in BrC samples in menopausal women.
\end{abstract}

\section{Introduction}

For many years, associations between thyroid disorders and breast cancer $(\mathrm{BrC})$ have raised questions regarding the involvement of thyroid hormone (TH) (either associated with estrogen receptor or not) on the development and progression of breast cancer, and significant research efforts have focused on this area [1-10]. Recently a study first showed that TH levels in postmenopausal women are positively related to $\mathrm{BrC}$ risk in a dose-response manner [9].

Prognostic and predictive factors are indispensable tools in neoplastic disease treatment [11], and estrogen receptor (ER) concentration is an important parameter in $\mathrm{BrC}$ prognosis [12]; ER status is an important consideration for $\mathrm{BrC}$ antiestrogen treatment [13]. Therefore, the presence and concentration of ER provide crucial information regarding tumors that respond to hormonal intervention [14]. Positive ER detection in $\mathrm{BrC}$ tissues is an indication of a tumor with hormonal dependence and indicates the benefit of endocrine therapy to this type of $\mathrm{BrC}$ [15]. Additionally, identification of positive or negative ER tumors can direct therapeutic strategies and clinical prognosis [16-18].

Given the known effect of $\mathrm{TH}$ on $\mathrm{BrC}$, there is little information about how this hormone binds with the receptors of breast tumor cells. Previous research demonstrated TH receptors in the nuclei of MCF-7 cells [19], while other works confirmed the presence of $\mathrm{TH}$ receptors in $\mathrm{BrC}$ tissue, but without correlation with other hormonal receptors (ER or progesterone receptor) or tumor progression [20]. Shao et al. [21] showed that triiodothyronine (T3) potentiates estrogen action on ER-positive $\mathrm{BrC}$ cell lines. 
We previously performed in vitro studies in MCF-7 and MDA-MB-231 cell lines to show that a supraphysiological concentration of T3 induces cell proliferation and expression of genes previously stimulated by estradiol (E2) independent of ER, with inhibition of T3 induction by tamoxifen (TAM) [7].

It is recognized that $\mathrm{E} 2$ and the hormonal status of a patient are important in $\mathrm{BrC}$ cell proliferation and treatment [15], and with respect to T3, while epidemiological studies have produced contradictory data regarding its effect on $\mathrm{BrC}$ [1, 22-27], laboratory studies have demonstrated its ability to induce $\mathrm{BrC}$ proliferation in a ER-dependent manner, possibly through crosstalk between the $\mathrm{TH}$ and $\mathrm{E} 2$ pathways $[3,7,28]$.

We investigated thyroid hormones levels in menopausal $\mathrm{BrC}$ patients because of their lack of estrogen and verified the action of T3 on genes regulated by E2 (TGFA, TGFB1, and PGR) [7] and T3 (TNFRSF9, BMP6, and THRA) [29] in primary BrC tissues exhibiting the early stages of tumor progression.

\section{Methods}

2.1. Patients. The study was approved by the Cancer Hospital, Antônio Prudente Foundation, São Paulo, Brazil, and Ethics Committee, and all patients signed an informed consent form. Patients recruited to this study were newly diagnosed with breast cancer and underwent surgery at the Cancer Hospital, Antônio Prudente Foundation, São Paulo, Brazil. All cases were classified as tumor node metastasis stage I or II. Ages ranged from 48 to 55 years, and all patients were menopausal (amenorrhea for at least 1 year).

Patients were excluded for the following reasons: radioor chemotherapy administration before surgery, hormone replacement therapy, any kind of previously diagnosed thyroid disease, chronic kidney failure, or recent elevation in serum creatinine values over those normally expected for that particular age. Other exclusion factors were abnormal hepatic function with aspartate aminotransferase, alanine aminotransferase, bilirubin, or alkaline phosphatase concentrations higher than twice the normal upper limit; use of $\beta$-blocking agents, aspirin, heparin, phenytoin, steroids, or dopamine in the month before or during the study; use of iodine-containing contrast agents in the six months before and during the study.

A control group consisted of 18 women aged 47 to 57 years whose recent mammograms indicated the absence of breast cancer. These mammograms were performed in the same week when anamnesis and blood samples were collected.

2.2. Immunohistochemistry. The presence of ER and progesterone receptors (PR) in tumors was determined by immunohistochemical staining using a monoclonal antibody to ER $\alpha$ (Upstate Biotechnology Inc., Lake Placid, NY, USA) and a monoclonal anti-PR antibody 636 (M3569, DakoCytomation). Biotinylated secondary antibodies (anti-mouse IgG or anti-rabbit $\operatorname{IgG}$ ) were obtained from Vector Laboratories (Burlingame, CA, USA). Endogenous peroxidase in tissue sections was blocked by incubation with a solution of $1 \%$ hydrogen peroxide for $30 \mathrm{~min}$, and antigen retrieval was performed by microwaving sections in $0.01 \mathrm{M}$ citrate buffer ( $\mathrm{pH} \mathrm{6.0)}$ for $20 \mathrm{~min}$ at $800 \mathrm{~W}$. Antibodies were diluted individually in PBS containing 3\% BSA. ER $\alpha$ antibody was used at a dilution of $1: 500$ and PR antibody was used at $1: 100$. Prior to addition of secondary antibody, tissue sections were rinsed in PBS containing $0.05 \%$ Tween 20 . The reactions were developed with an avidin-biotin-peroxidase complex. Tumors known to be positive for the studied marker were considered to be positive controls. Tumors were considered positive with a moderate intensity of staining and the proportion of this intensity at more than $10 \%$ of cells [30].

2.3. Serum Dosage. Serum aliquots were analyzed for thyroid peroxidase antibody (TPOab), thyroid-stimulating hormone (TSH), free thyroxine (FT4), and E2 using commercially available kits (DPC, Los Angeles, CA, USA). The normal ranges were $<35.0 \mathrm{UI} / \mathrm{mL}$ for anti-TPO negative, $0.4-4.0 \mu \mathrm{U} / \mathrm{mL}$ for TSH, $0.8-2.0 \mathrm{ng} / \mathrm{dL}$ for FT4, and $0.0-$ $30.0 \mathrm{pg} / \mathrm{mL}$ for E2 (after menopause).

2.4. Chemicals. E2, T3, and TAM were purchased from Sigma. Each was dissolved in ethanol to give a stock solution and used diluted for use in culture at the following concentrations: E2 at a physiological concentration of $10^{-8} \mathrm{M}, \mathrm{T} 3$ at a supraphysiological concentration of $10^{-8} \mathrm{M}$, and TAM at a pharmacological concentration of $10^{-6} \mathrm{M}$ [7].

2.5. Primary Culture. Fresh human breast carcinoma tissue remaining after pathological and prognostic analysis was obtained from collaborating surgeons and pathologists; it was trimmed free of fat and placed in phosphate-buffered saline. A Krumdieck tissue slicer (Alabama Research Corporation) was used to obtain $0.3 \mathrm{~mm}$ slices. Slices were divided into six $35 \mathrm{~mm}$ dishes and placed on siliconized lens paper floating in $2 \mathrm{~mL}$ organ culture medium. Each treatment was performed in a single dish containing 2 to 3 slices. Primary tissue was cultured in phenol-red-free RPMI supplemented with $10 \mathrm{U} / \mathrm{mL}$ penicillin, $100 \mu \mathrm{g} / \mathrm{mL}$ streptomycin, $500 \mu \mathrm{g} / \mathrm{mL} \mathrm{BSA}$, and $5 \mu \mathrm{g} / \mathrm{mL}$ insulin (Life Technologies Corporation, Carlsbad, CA, USA). Dishes received the following treatments: dish 1: ethanol; dish 2: T3 $\left(10^{-8} \mathrm{M}\right)$; dish 3: T3 $\left(10^{-8} \mathrm{M}\right)$ plus TAM $\left(10^{-6} \mathrm{M}\right)$; dish 4: TAM $\left(10^{-6} \mathrm{M}\right)$; dish 5: E2 $\left(10^{-8} \mathrm{M}\right)$; dish 6: E2 $\left(10^{-8} \mathrm{M}\right)$ plus TAM $\left(10^{-6} \mathrm{M}\right)$. Cultures were maintained at $37^{\circ} \mathrm{C}$ in a humidified atmosphere of $95 \%$ air $/ 5 \% \mathrm{CO}_{2}$. Medium changes were performed after $24 \mathrm{~h}$ and harvesting was performed after $48 \mathrm{~h}$ [31].

2.6. RNA Isolation and Reverse Transcription. Total RNA was extracted from slices by the guanidinium thiocyanate method and analyzed by electrophoresis using 1\% agarose gels. One microgram of total RNA was reverse transcribed with SuperScript III First-Strand Synthesis System for RTPCR (Invitrogen, no. 18080-051). 
2.7. Measurement of Gene Expression by Quantitative RealTime PCR. The real-time RT-PCR method with an Assayon-Demand Gene Expression Product (Life Technologies, $\mathrm{P} / \mathrm{N}$ 4331182) consisted of unlabeled PCR primers and a TaqMan MGB probe (FAM dye-labeled) optimized to work with the TaqMan Universal PCR Master Mix (P/N 4304437) in an ABI Prism 7700 system (PerkinElmer Life Sciences, Boston, MA, USA) and was employed to quantitatively measure transforming growth factor alpha (TGFA; Hs00608187_m1), transforming growth factor beta 1 (TGFB1; Hs00998133_m1), progesterone receptor (PGR; Hs01556702_m1), tumor necrosis factor receptor superfamily member 9 (TNFRSF9; Hs00155512_m1), bone morphogenetic protein 6 (BMP6; Hs01099594_m1), thyroid hormone receptors $\alpha / \beta$ (THRA; Hs00268470_m1, and THRB; Hs00230861_m1), and glyceraldehyde-3-phosphate dehydrogenase (GAPDH; Hs02758991_g1) mRNA expression (Applied Biosystems). All assays were performed in triplicate. The mRNA contents were normalized to GAPDH mRNA levels, and differences in expression were determined by the CT method described in the ABI user's manual (Life Technologies).

2.8. Statistical Analysis. Serum dosages were compared by nonparametric analysis of variance for the two-factor model $(P<0.05$, Mann-Whitney test $)$.

Gene expression comparisons were performed by the analysis of variance technique for an experiment with completely randomized blocks, complemented by the Tukey multiple comparison test for pairs of measurements, or the equivalent nonparametric procedure when data were not normally distributed. The level of significance was set at $95 \%$ $(P<0.05)$ for all presented data.

\section{Results}

3.1. Hormonal Status and Immunohistochemistry. Fresh tumor samples were used for ER and PR immunohistochemistry. Two samples were negative for ER, and six were negative for PR. ER-negative samples were excluded from gene expression analysis.

Serum determinations were performed prior to surgery. After surgery, new serum determinations were performed to confirm the previously obtained data. Three patients (numbers 01, 05, and 14) presented with clinical hyperthyroidism (low TSH with high FT4), while one patient (number 06) was positive for TPOab, and one patient (number 11) showed subclinical hypothyroidism (high TSH with normal FT4) (Table 1). There were no differences in E2 levels between controls and $\mathrm{BrC}$ patients. $\mathrm{BrC}$ patients presented with no significant differences in E2 and TSH levels compared with control patients. Mean serum values for thyroid hormone were statistically higher in $\mathrm{BrC}$ than control patients. TPOab was not observed in controls. FT4 levels were significantly higher in $\mathrm{BrC}$ patients than in controls (Table 2).

3.2. Primary Culture. All the tissues included in this study were positive for estrogen receptor and thyroid hormone receptor expression.

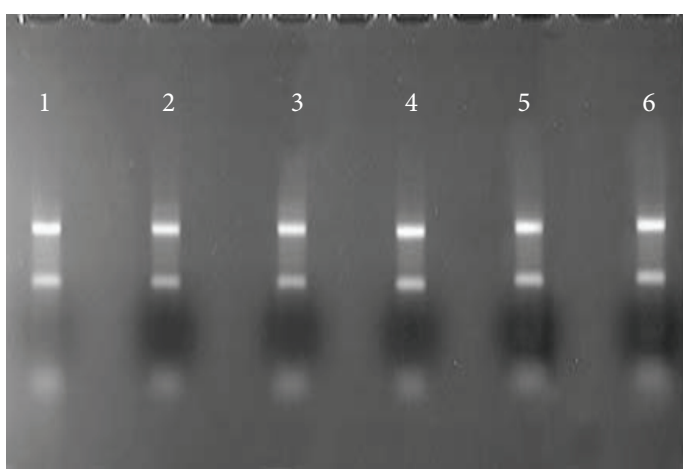

FIGURE 1: Total RNA from primary culture of breast tumor for different postsurgery treatment periods on a $1 \%$ agarose gel $(1: 8 \mathrm{~h}$; $2: 16 \mathrm{~h} ; 3: 24 \mathrm{~h} ; 4: 32 \mathrm{~h} ; 5: 40 \mathrm{~h} ; 6: 48 \mathrm{~h})$.

To ascertain whether extracted mRNA quality was affected by treatment time, a $1 \%$ agarose gel test was used to evaluate intervals of $8,16,24,32,40$, and $48 \mathrm{~h}$ (Figure 1). Of note, normal breast tissue from patients undergoing mammoplasty was negative for mRNA expression of the studied genes.

3.3. Gene Expression and Evidence of Thyroid Hormone Influence. Figure 2 shows box plots that represent the expression of each gene following stimulation by E2 (TGFA, TGFB1, and $P G R)$ after administration of the previously described treatments; Figure 3 details the respective data for T3 (TNFRSF9, BMP-6, and THRA). Patients 01, 05, and 14 (with amended thyroid hormone status) and patients 03 and10 (negative ER) were excluded from these data.

\section{Discussion}

4.1. Hormonal Status and Immunohistochemistry. There is much evidence suggesting a relationship between thyroid disease and $\mathrm{BrC}$ risk but it is controversial. Numerous studies have been conducted, and some have found no significant relationship between thyroid disease [32] or treatment of thyroid disease [33] and $\mathrm{BrC}$ risk, while others correlated BrC with hyperthyroidism $[1,10,34,35]$, hypothyroidism [24, $36,37]$, nontoxic goiter $[8,38,39]$, or thyroid autoimmune diseases [8, 37, 38, 40-42].

With respect to thyroid diseases, previous studies of postmenopausal women have reported higher hypothyroidism incidence concurrent with $\mathrm{BrC}$ compared with women with other tumor types or normal controls [24]. These data were confirmed by studies on women with $\mathrm{BrC}$ independent of E2 status [35, 36, 42]. However, several studies were unable to confirm a relationship between hypothyroidism and $\mathrm{BrC}$ $[39,43]$. Thyroid autoimmune disease is identified by TPOab positivity; several works identified higher TPOab in $\mathrm{BrC}$ patients than controls $[8,38,41,42]$. Autoimmune cases as well as nontoxic goiters are common in $\mathrm{BrC}$ cases. Some works have shown significant increased thyroid volume in these cases $[8,42]$. 
TABLE 1: Tumor staging, immunohistochemistry, and serum dosage of breast cancer patients.

\begin{tabular}{|c|c|c|c|c|c|c|}
\hline \multirow{2}{*}{ Case number } & \multirow{2}{*}{ Staging } & \multirow{2}{*}{ Immunohistochemistry } & \multicolumn{4}{|c|}{ Serum dosage } \\
\hline & & & $\operatorname{TPOAb}^{(1)}(\mathrm{UI} / \mathrm{mL})$ & $\mathrm{TSH}^{(2)}(\mu \mathrm{I} / \mathrm{mL})$ & $\mathrm{FT} 4^{(3)}(\mathrm{ng} / \mathrm{dL})$ & $\mathrm{E} 2^{(4)}(\mathrm{pg} / \mathrm{mL})$ \\
\hline $1^{\mathrm{a}}$ & $\mathrm{T}(2) \mathrm{N}(1) \mathrm{M}(0)$ & $\mathrm{ER}(+) ; \mathrm{PR}(+)$ & 11.50 & 0.03 & 3.38 & $<20.00$ \\
\hline 2 & $\mathrm{~T}(2) \mathrm{N}(0) \mathrm{M}(0)$ & $\mathrm{ER}(+) ; \operatorname{PR}(-)$ & $<10.00$ & 3.03 & 1.48 & 26.70 \\
\hline 3 & $\mathrm{~T}(2) \mathrm{N}(0) \mathrm{M}(0)$ & $\mathrm{ER}(-) ; \operatorname{PR}(-)$ & 22.30 & 1.22 & 1.78 & $<20.00$ \\
\hline 4 & $\mathrm{~T}(1) \mathrm{N}(0) \mathrm{M}(0)$ & $\mathrm{ER}(+) ; \operatorname{PR}(+)$ & 22.90 & 0.96 & 1.44 & 26.80 \\
\hline $5^{\mathrm{a}}$ & $\mathrm{T}(2) \mathrm{N}(0) \mathrm{M}(0)$ & $\mathrm{ER}(+) ; \operatorname{PR}(+)$ & $<10.00$ & 0.30 & 1.94 & $<20.00$ \\
\hline $6^{b, c}$ & $\mathrm{~T}(1) \mathrm{N}(2) \mathrm{M}(0)$ & $\mathrm{ER}(+) ; \mathrm{PR}(+)$ & 354.00 & 5.11 & 1.26 & $<20.00$ \\
\hline 7 & $\mathrm{~T}(2) \mathrm{N}(1) \mathrm{M}(0)$ & $\mathrm{ER}(+) ; \operatorname{PR}(-)$ & $<10.00$ & 1.85 & 2.30 & 26.90 \\
\hline 8 & $\mathrm{~T}(2) \mathrm{N}(0) \mathrm{M}(0)$ & $\operatorname{ER}(+) ; \operatorname{PR}(-)$ & 23.90 & 1.83 & 1.75 & 26.10 \\
\hline 9 & $\mathrm{~T}(1) \mathrm{N}(0) \mathrm{M}(0)$ & $\mathrm{ER}(+) ; \mathrm{PR}(+)$ & 13.50 & 1.34 & 1.85 & 28.20 \\
\hline 10 & $\mathrm{~T}(2) \mathrm{N}(1) \mathrm{M}(0)$ & $\operatorname{ER}(-) ; \operatorname{PR}(+)$ & 18.40 & 0.92 & 1.85 & 23.80 \\
\hline $11^{\mathrm{b}}$ & $\mathrm{T}(2) \mathrm{N}(0) \mathrm{M}(0)$ & $\mathrm{ER}(+) ; \mathrm{PR}(+)$ & $<10.00$ & 4.47 & 1.39 & $<20.00$ \\
\hline 12 & $\mathrm{~T}(2) \mathrm{N}(0) \mathrm{M}(0)$ & $\mathrm{ER}(+) ; \operatorname{PR}(-)$ & $<10.00$ & 1.60 & 1.53 & $<20.00$ \\
\hline 13 & $\mathrm{~T}(2) \mathrm{N}(1) \mathrm{M}(0)$ & $\mathrm{ER}(+) ; \mathrm{PR}(+)$ & 11.90 & 1.80 & 1.77 & $<20.00$ \\
\hline $14^{\mathrm{a}}$ & $\mathrm{T}(1) \mathrm{N}(0) \mathrm{M}(0)$ & $\mathrm{ER}(+) ; \operatorname{PR}(-)$ & $<10.00$ & 0.29 & 3.06 & 26.70 \\
\hline 15 & $\mathrm{~T}(2) \mathrm{N}(0) \mathrm{M}(0)$ & $\mathrm{ER}(+) ; \mathrm{PR}(+)$ & 15.70 & 0.76 & 1.78 & 24.50 \\
\hline
\end{tabular}

${ }^{(1)}$ Thyroid peroxidase antibody $(\mathrm{TPOab}):<35.00 \mathrm{UI} / \mathrm{mL}=$ negative.

${ }^{(2)}$ Thyroid-stimulating hormone (TSH): normality between 0.4 and $4.0 \mathrm{mUI} / \mathrm{mL}$.

${ }^{(3)}$ Free thyroxine (FT4): normality between 0.8 and $1.9 \mathrm{ng} / \mathrm{dL}$.

${ }^{(4)}$ Estradiol (E2): normality on postmenopause between 0 and $30 \mathrm{pg} / \mathrm{mL}$.

${ }^{\text {a }}$ Hyperthyroidism.

${ }^{\mathrm{b}}$ Subclinical hypothyroidism.

${ }^{\mathrm{c}} \mathrm{TPOab}$ positive.

TABLE 2: Comparison of hormonal dosages between breast cancer and normal control patients.

\begin{tabular}{lcc}
\hline & Breast cancer $(N=15)$ & Control $(N=18)$ \\
\hline TSH $(\mu \mathrm{I} / \mathrm{mL})$ & $1.34 \pm 0.60$ & $2.41 \pm 1.10$ \\
FT4 $(\mathrm{ng} / \mathrm{dL})$ & $1.78 \pm 0.20^{*}$ & $0.95 \pm 0.16$ \\
E2 $(\mathrm{pg} / \mathrm{mL})$ & $23.80 \pm 3.35$ & $21.80 \pm 3.29$ \\
\hline
\end{tabular}

Data are reported as median \pm total semirange. TSH: thyroid-stimulating hormone; FT4: free thyroxine; E2: estradiol. ${ }^{*} P<0.05$ compared with control group (Mann-Whitney test).

In our study, we identified a higher prevalence of thyroid disease $(33.3 \%)$, with hyperthyroidism being the most frequent condition (20.0\%), confirming previous reports [1,27].

4.2. Primary Culture. One of the major concerns for researchers working with breast cancer models is that these models may exhibit behavior that is dissimilar to that of breast cancer tissue in vivo. Burdall and colleagues [44] evaluated the use of breast cancer cell cultures and highlighted the advantages of these models in that they exhibit limitless selfreplication, are easily replaced with frozen stock, and demonstrate a relatively high degree of homogeneity. However, cell culture models are prone to genotypic and phenotypic drift, which excludes this model when considering and comparing individual characteristics of patients. A recent alternative approach has been aimed at minimizing the differences between in vitro culture models and living breast cancer tissue.
In contrast, culture of breast tumor slices does not present the effects of genetic drift, which may occur in cell lines during the course of passaging, and this method maintains some in vivo characteristics. Furthermore, breast tumor slices have been primarily useful for evaluating responses to hormonal and pharmacological treatments, showing gene expression results that are close to in vivo responses.

These data complement our understanding of how study models for breast cancer may present variations in results. It was previously observed by our group that TGFA expression in primary organ culture was not reproducible to the results seen in cell lines (5). Cell lines have advantages such as high genomic homogeneity that lead to little variation in the results when compared with primary organ cultures. However, it is now acknowledged that information regarding genomic variation is insignificant in comparison to the variability introduced during technical steps such as culture preparation and gene expression. In primary organ culture, variation in the data produced is higher than the natural variation introduced by the techniques used. These variations may reflect a heterogeneity that develops in different tumor samples because of the wide range of factors that lead to genomic instability.

4.3. Gene Expression and Evidence of Thyroid Hormone Influence. Some gene expression variation showing a marked action of E2 on breast cancer has already been established in previous works. We previously demonstrate upregulated TGFA and downregulated TGFB1 after E2 and T3 treatments. We reported this variation in breast cancer cells lines, with 

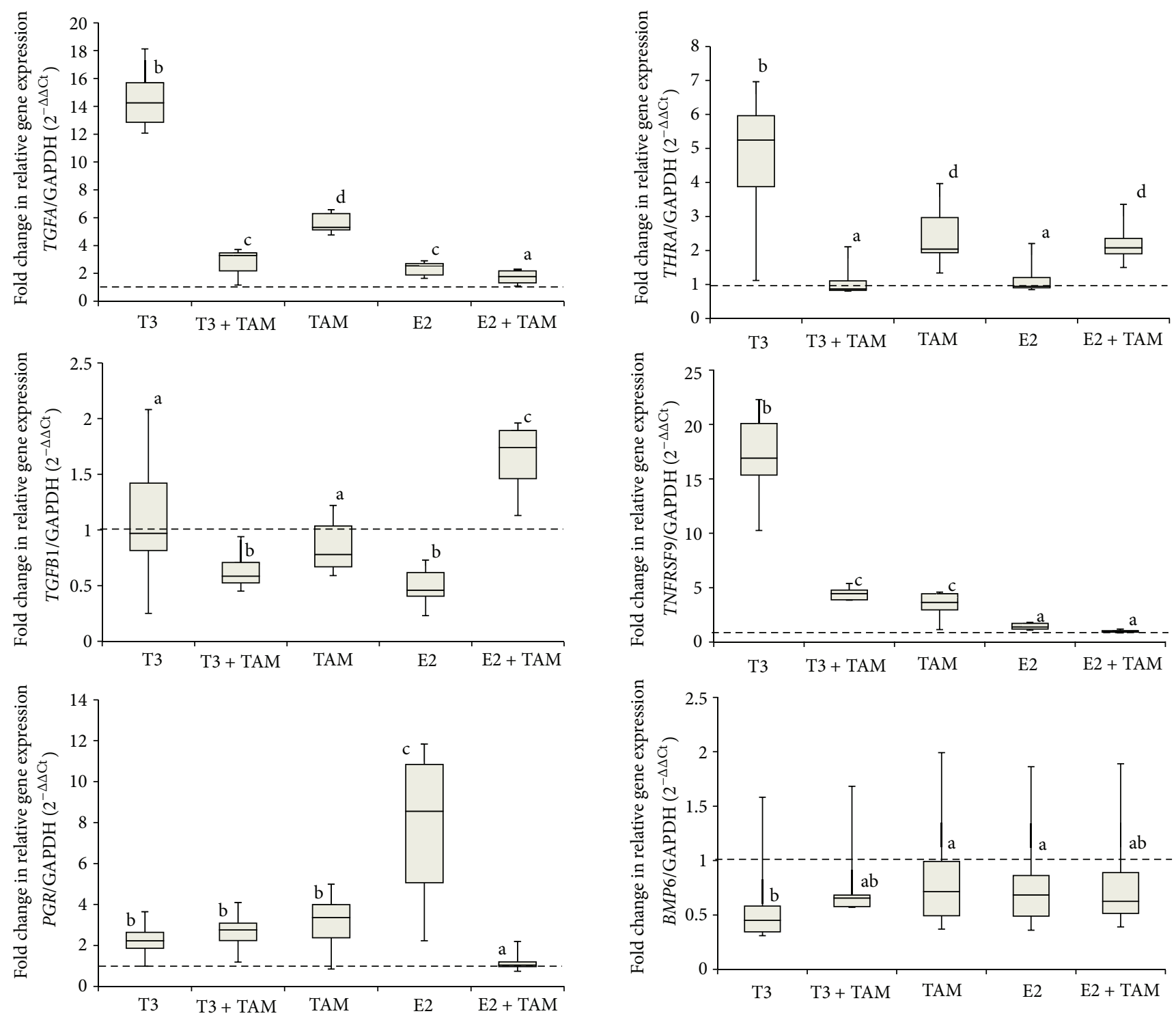

Figure 2: Gene expression of known estrogen-stimulated genes in primary cultures of breast tumors. Samples were treated as follows: ethanol vehicle, triiodothyronine (T3), T3 plus tamoxifen (TAM), TAM, estradiol (E2), and E2 plus TAM. After $48 \mathrm{~h}$ of treatment, TGFA, TGFB1, and PGR were quantified by real-time RTPCR. Glyceraldehyde-3-phosphate dehydrogenase (GAPDH) was used to normalize gene expression. Relative mRNA expression was calculated using the expression level of the treated ethanol sample as the standard set to the dotted line and represented by letter "a." Different letters indicate $P<0.05$.

estrogen receptor dependence [7]. When hormonal treatment was associated with TAM, variations in gene expression did not show statistical differences compared with control cells. However, although E2 and T3 treatment of primary cultures showed the same gene expression profile, TAM association did not block T3 treatment but rather increased TGFA and decreased TGFB1 gene expression during T3 and TAM association. Here, we choose PGR as a marker of estrogen action, as reported elsewhere [45]. As expected, E2 treatment

increased PGR expression and TAM association blocked this action. Although T3 treatment increased PGR expression, this action was less pronounced than E2; however, TAM did not block T3 action on PGR expression, diverging from data previously obtained from cell lines [7]. Treatment with TAM can inhibit E2 action, functioning like a partial antagonist of nuclear ER, but there is evidence for the agonistic action of TAM on plasma membrane receptors for E2 [46]. Our group has previously correlated PGR expression with TH [7], and 
here we provided evidence for the upregulation of PGR in primary culture treated with $\mathrm{T} 3$ plus TAM.

To confirm the action of T3 treatment, we verified the expression of previously described genes exhibiting upregulation (TNFRSF9 and THRA) or downregulation (4-1BB) under TH treatment [29]. Treatment of primary cultures with $\mathrm{T} 3$ and $\mathrm{E} 2$ reproduced equivalent results obtained in cell lines [7]. However, associations of these hormones with TAM did not reproduce these results. Acting as antagonist on ER, TAM associated with E2 maintained expression of TGFA and PGR to the control levels, but when T3 plus TAM association was applied, TGFA and TGFB1 expression was at the same levels as those following E2 treatment. This association may coincide with estrogenic response on gene expression and highlight the effect of TAM usage in hyperthyroid patients, especially considering the proliferative and apoptotic effects of TGFA and TGFB1, respectively, on the initial tumor progression stages. This finding was reinforced by observations of upregulated PGR expression under T3 treatment (although levels were less than those produced following E2 stimulation), which did not show changes with TAM association.

To assess whether E2 could influence the expression of T3 target genes, we examined the effect on TNFRSF9, BMP-6, and THRA expression and observed no differences in comparison to the control. E2 and TAM treatment upregulated THRA expression; however, this effect may be due only to TAM because it exerted the same upregulation effects as E2 plus TAM.

Note that TAM alone or associated with T3 modulated gene expression of TNFRSF9, BMP-6, and THRA related to the control, similar to T3 treatment, showing that the TAM can interfere with gene expression modulated by $\mathrm{T} 3$.

Our results showed that thyroid dysfunctions correlate with ER positivity (Table 1). There are many possibilities of crosstalk between T3, E2, and TAM. Some previous research considered $\mathrm{TH}$ and ER binding, as demonstrated in $\mathrm{BrC}$ cell lines [7]. On the other hand, TH can alter ER-dependent gene transcription, with ER-thyroid hormone receptor dimer formation that results in flexible regulation of the consensus ERE [28], or interaction between thyroid hormone receptors and ERE [3]. Most recently, studies have emphasized the nongenomic actions of $\mathrm{T} 3$ and $\mathrm{E} 2$, commencing at the receptors at the plasma membrane or in the cytoplasm and activating intracellular signaling pathways such as PI3 K or MAPK. The E2 antagonist fulvestrant does not activate these signaling pathways by this mechanism, but other selective estrogen receptor modulators (SERM), such as TAM, do it in a similar manner to E2, showing that TAM confers an antagonistic action on nuclear ER but an agonistic action on membrane ER [47, 48]. AKT and MAPK phosphorylation can elevate agonistic TAM and other SERM activity [48].

\section{Conclusions}

Our work identified a high incidence of hyperthyroidism in menopausal women with $\mathrm{BrC}$, who exhibited a higher degree of TH than the control group. Primary culture of tumor samples was utilized to evaluate gene expression modified by T3 or E2 treatment and produced similar but not identical results to those observed in breast cancer cell lines. T3 had a significant effect on genes classically regulated by E2, but the combination of T3 with TAM did not reverse gene expression levels to those observed in the untreated control group, in contrast to E2 plus TAM, which resulted in maintained gene expression when $\mathrm{E} 2$ treatment was applied. Taking into account the known ability of TH to mimic the effects of E2, particularly in the presence of TAM, our results reinforce previous reports that the thyroid hormone status of $\mathrm{BrC}$ patients can influence E2-controlled mechanisms, even under TAM intervention and/or the absence of circulating E2 in postmenopausal women. Thus, our study highlights the importance of evaluation of thyroid hormone status when considering the prognosis and treatment options for individual patients.

\section{Abbreviations

$\begin{array}{ll}\text { BrC: } & \text { Breast cancer } \\ \text { TH: } & \text { Thyroid hormone } \\ \text { ER: } & \text { Estrogen receptor } \\ \text { T3: } & \text { Triiodothyronine } \\ \text { E2: } & \text { Estradiol } \\ \text { TAM: } & \text { 4-Hydroxytamoxifen } \\ \text { PR: } & \text { Progesterone receptor } \\ \text { TPOab: } & \text { Thyroid peroxidase antibody } \\ \text { TSH: } & \text { Thyroid-stimulating hormone } \\ \text { FT4: } & \text { Free thyroxine } \\ \text { TGFA: } & \text { Transforming growth factor alpha } \\ \text { TGFB1: } & \text { Transforming growth factor beta } 1 \\ \text { PGR: } & \text { Progesterone receptor }\end{array}$ \\ TNFRSF9: Tumor necrosis factor receptor superfamily 9 \\ BMP-6: Bone morphogenetic protein 6 \\ THRA: Thyroid hormone receptor alpha.}

\section{Conflict of Interests}

The authors declare that there is no conflict of interests regarding the publication of this paper.

\section{Acknowledgments}

This study was supported by FAPESP Grant 05/554591 and 13/11111-8 and supported by CAPES/PNPD Grant 00000.059158/2010.

\section{References}

[1] P. P. Saraiva, N. B. Figueiredo, C. R. Padovani, M. M. Brentani, and C. R. Nogueira, "Profile of thyroid hormones in breast cancer patients," Brazilian Journal of Medical and Biological Research, vol. 38, no. 5, pp. 761-765, 2005.

[2] I. Conde, R. Paniagua, J. Zamora et al., "Influence of thyroid hormone receptors on breast cancer cell proliferation," Annals of Oncology, vol. 17, no. 1, pp. 60-64, 2006. 
[3] S. Dinda, A. Sanchez, and V. Moudgil, "Estrogen-like effects of thyroid hormone on the regulation of tumor suppressor proteins, p53 and retinoblastoma, in breast cancer cells," Oncogene, vol. 21, no. 5, pp. 761-768, 2002.

[4] S. J. Conde, R. D. A. M. Luvizotto, M. T. de Síbio, and C. R. Nogueira, "Human breast tumor slices as an alternative approach to cell lines to individualize research for each patient," European Journal of Cancer Prevention, vol. 21, no. 4, pp. 333335, 2012.

[5] S. J. Conde, R. A. M. Luvizotto, M. T. Sibio, M. L. H. Katayama, M. M. Brentani, and C. R. Nogueira, "Tamoxifen inhibits transforming growth factor- $\alpha$ gene expression in human breast carcinoma samples treated with triiodothyronine," Journal of Endocrinological Investigation, vol. 31, no. 12, pp. 1047-1051, 2008.

[6] S. H. Cestari, N. B. Figueiredo, S. J. Conde et al., "Influence of estradiol and triiodothyronine on breast cancer cell lines proliferation and expression of estrogen and thyroid hormone receptors," Arquivos Brasileiros de Endocrinologia e Metabologia, vol. 53, no. 7, pp. 859-864, 2009.

[7] C. R. Nogueira and M. M. Brentani, "Triiodothyronine mimics the effects of estrogen in breast cancer cell lines," Journal of Steroid Biochemistry and Molecular Biology, vol. 59, no. 3-4, pp. 271-279, 1996.

[8] O. Turken, Y. NarIn, S. DemIrbas et al., "Breast cancer in association with thyroid disorders," Breast Cancer Research, vol. 5, no. 5, pp. R110-R113, 2003.

[9] A. Tosovic, A.-G. Bondeson, L. Bondeson, U.-B. Ericsson, J. Malm, and J. Manjer, "Prospectively measured triiodothyronine levels are positively associated with breast cancer risk in postmenopausal women," Breast Cancer Research, vol. 12, no. 3, article R33, 2010.

[10] M. Lemaire and L. Baugnet-Mahieu, "Thyroid function in women with breast cancer," European Journal of Cancer and Clinical Oncology, vol. 22, no. 3, pp. 301-307, 1986.

[11] M. West, C. Blanchette, H. Dressman et al., "Predicting the clinical status of human breast cancer by using gene expression profiles," Proceedings of the National Academy of Sciences of the United States of America, vol. 98, no. 20, pp. 11462-11467, 2001.

[12] M. Lacroix, G. Querton, P. Hennebert, D. Larsimont, and G. Leclercq, "Estrogen receptor analysis in primary breast tumors by ligand-binding assay, immunocytochemical assay, and northern blot: a comparison," Breast Cancer Research and Treatment, vol. 67, no. 3, pp. 263-271, 2001.

[13] S. Sommer and S. A. W. Fuqua, "Estrogen receptor and breast cancer," Seminars in Cancer Biology, vol. 11, no. 5, pp. 339-352, 2001.

[14] S. A. W. Fuqua, G. C. Chamness, and W. L. McGuire, "Estrogen receptor mutations in breast cancer," Journal of Cellular Biochemistry, vol. 51, no. 2, pp. 135-139, 1993.

[15] E. V. Jensen, G. Cheng, C. Palmieri et al., "Estrogen receptors and proliferation markers in primary and recurrent breast cancer," Proceedings of the National Academy of Sciences of the United States of America, vol. 98, no. 26, pp. 15197-15202, 2001.

[16] D. P. Edwards, G. C. Chamness, and W. L. McGuire, "Estrogen and progesterone receptor in breast cancer," Biochimica et Biophysica Acta, vol. 560, no. 4, pp. 457-486, 1979.

[17] L. Bernstein and R. K. Ross, "Endogenous hormones and breast cancer risk," Epidemiologic Reviews, vol. 15, no. 1, pp. 48-65, 1993.

[18] L. A. Habel and J. L. Stanford, "Hormone receptors and breast cancer," Epidemiologic Reviews, vol. 15, no. 1, pp. 209-219, 1993.
[19] R. E. Burke and W. L. McGuire, "Nuclear thyroid hormone receptors in a human breast cancer cell line," Cancer Research, vol. 38, no. 11 I, pp. 3769-3773, 1978.

[20] M.-A. Cerbon, M.-F. Pichon, and E. Milgrom, “Thyroid hormone receptors in human breast cancer," Cancer Research, vol. 41, no. 10, pp. 4167-4173, 1981.

[21] Z.-M. Shao, M. S. Sheikh, A. K. Rishi et al., "Thyroid hormone enhancement of estradiol stimulation of breast carcinoma proliferation," Experimental Cell Research, vol. 218, no. 1, pp. 1-8, 1995.

[22] J. G. Spencer, "The influence of the thyroid in malignant disease," British Journal of Cancer, vol. 8, no. 3, pp. 393-411, 1954.

[23] O. Muhlbock and L. M. Boot, "Induction of mammary cancer in mice without the mammary tumor agent by," Cancer Research, vol. 19, no. 4, pp. 402-412, 1959.

[24] D. P. Rose and T. E. Davis, "Plasma thyroid-stimulating hormone and thyroxine concentrations in breast cancer," Cancer, vol. 41, no. 2, pp. 666-670, 1978.

[25] B. S. Thomas, R. D. Bulbrook, and M. J. Russell, "Thyroid function in early breast cancer," European Journal of Cancer and Clinical Oncology, vol. 19, no. 9, pp. 1213-1219, 1983.

[26] H. Vorherr, "Thyroid function in benign and malignant breast disease," European Journal of Cancer and Clinical Oncology, vol. 23 , no. 3, pp. $255-257,1987$.

[27] O. Takatani, T. Okumoto, H. Kosano, M. Nishida, H. Hiraide, and S. Tamakuma, "Relationship between the levels of serum thyroid hormones or estrogen status and the risk of breast cancer genesis in Japanese women," Cancer Research, vol. 49, no. 11, pp. 3109-3112, 1989.

[28] N. Vasudevan, N. Koibuchi, W. W. Chin, and D. W. Pfaff, "Differential crosstalk between estrogen receptor (ER) $\alpha$ and $\operatorname{ER} \beta$ and the thyroid hormone receptor isoforms results in flexible regulation of the consensus ERE," Molecular Brain Research, vol. 95, no. 1-2, pp. 9-17, 2001.

[29] T. Yamada-Okabe, Y. Satoh, and H. Yamada-Okabe, “Thyroid hormone induces the expression of $4-1 \mathrm{BB}$ and activation of caspases in a thyroid hormone receptor-dependent manner," European Journal of Biochemistry, vol. 270, no. 14, pp. 30643073, 2003.

[30] S. R. Lakhani, M. J. van de Vijver, J. Jacquemier et al., "The pathology of familial breast cancer: predictive value of immunohistochemical markers estrogen receptor, progesterone receptor, HER-2, and $\mathrm{p} 53$ in patients with mutations in BRCA1 and BRCA2," Journal of Clinical Oncology, vol. 20, no. 9, pp. 2310-2318, 2002.

[31] R. Mira-y-Lopez and L. Ossowski, "Preservation of steroid hormone receptors in organ cultures of human breast carcinomas," Cancer Research, vol. 50, no. 1, pp. 78-83, 1990.

[32] A. Kalache, M. P. Vessey, and K. McPherson, "Thyroid disease and breast cancer: findings in a large case-control study," British Journal of Surgery, vol. 69, no. 7, pp. 434-435, 1982.

[33] H. A. Weiss, L. A. Brinton, N. A. Potischman et al., "Breast cancer risk in young women and history of selected medical conditions," International Journal of Epidemiology, vol. 28, no. 5, pp. 816-823, 1999.

[34] A. R. Moossa, D. A. Price Evans, and A. C. Brewer, "Thyroid status and breast cancer: reappraisal of an old relationship," Annals of the Royal College of Surgeons of England, vol. 53, no. 3, pp. 178-188, 1973.

[35] M. B. Goldman, “Thyroid diseases and breast cancer," Epidemiologic Reviews, vol. 12, pp. 16-28, 1990. 
[36] I. Mittra and J. L. Hayward, "Hypothalamic-pituitary-thyroid axis in breast cancer," The Lancet, vol. 1, no. 7863, pp. 885-889, 1974.

[37] D. A. Adamopoulos, S. Vassilaros, and N. Kapolla, "Thyroid disease in patients with benign and malignant mastopathy," Cancer, vol. 57, no. 1, pp. 125-128, 1986.

[38] C. Giani, P. Fierabracci, R. Bonacci et al., "Relationship between breast cancer and thyroid disease: relevance of autoimmune thyroid disorders in breast malignancy," Journal of Clinical Endocrinology and Metabolism, vol. 81, no. 3, pp. 990-994, 1996.

[39] P. P. A. Smyth, D. F. Smith, E. W. M. McDermott, M. J. Murray, J. G. Geraghty, and N. J. O'Higgins, "A direct relationship between thyroid enlargement and breast cancer," Journal of Clinical Endocrinology and Metabolism, vol. 81, no. 3, pp. 937-941, 1996.

[40] K. Itoh and N. Maruchi, "Breast cancer in patients with Hashimoto's thyroiditis," The Lancet, vol. 2, no. 7945, pp. 11191121, 1975.

[41] B. Rasmusson, U. Feldt-Rasmussen, and L. Hegedus, “Thyroid function in patients with breast cancer," European Journal of Cancer and Clinical Oncology, vol. 23, no. 5, pp. 553-556, 1987.

[42] P. P. A. Smyth, S. G. Shering, M. T. Kilbane et al., "Serum thyroid peroxidase autoantibodies, thyroid volume, and outcome in breast carcinoma," Journal of Clinical Endocrinology and Metabolism, vol. 83, no. 8, pp. 2711-2716, 1998.

[43] A. J. Hedley, S. J. Jones, and D. J. Spiegelhalter, "Breast cancer in thyroid disease: fact or fallacy?" The Lancet, vol. 1, no. 8212, pp. 131-133, 1981.

[44] S. E. Burdall, A. M. Hanby, M. R. J. Lansdown, and V. Speirs, "Breast cancer cell lines: friend or foe?" Breast Cancer Research, vol. 5, no. 2, pp. 89-95, 2003.

[45] J. Rokicki, P. M. Das, J. M. Giltnane et al., “The ER $\alpha$ coactivator, HER4/4ICD, regulates progesterone receptor expression in normal and malignant breast epithelium," Molecular Cancer, vol. 9, article 150, 2010.

[46] C. K. Osborne and R. Schiff, "Estrogen-receptor biology: continuing progress and therapeutic implications," Journal of Clinical Oncology, vol. 23, no. 8, pp. 1616-1622, 2005.

[47] E. R. Levin, "Cellular functions of plasma membrane estrogen receptors," Steroids, vol. 67, no. 6, pp. 471-475, 2002.

[48] J. Shou, S. Massarweh, C. K. Osborne et al., "Mechanisms of tamoxifen resistance: increased estrogen receptor-HER2/neu cross-talk in ER/HER2-positive breast cancer," Journal of the National Cancer Institute, vol. 96, no. 12, pp. 926-935, 2004. 


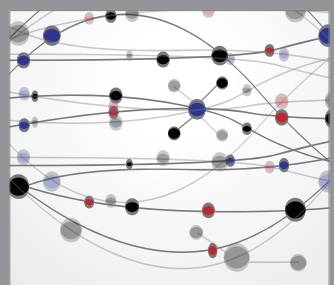

The Scientific World Journal
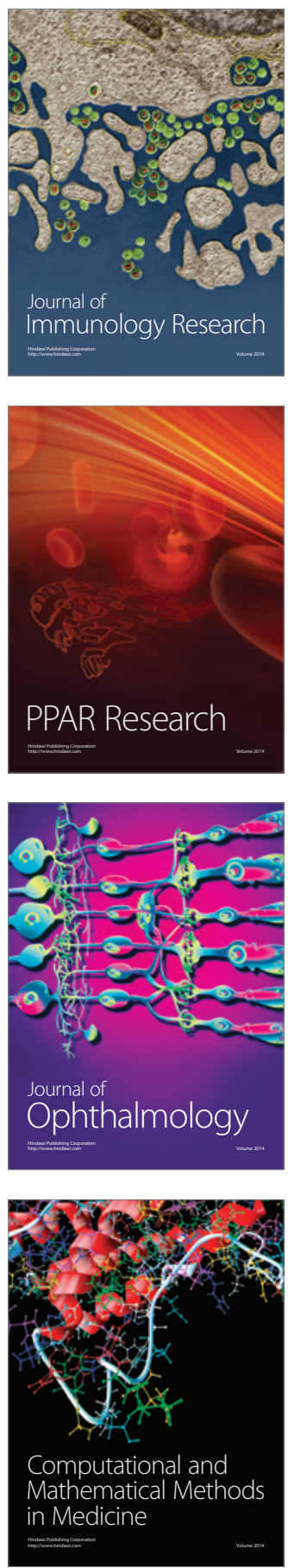

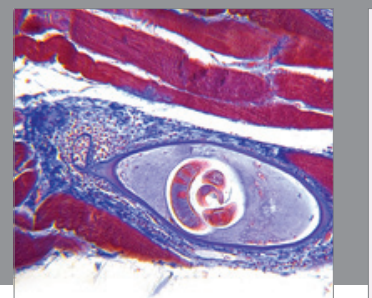

Gastroenterology

Research and Practice
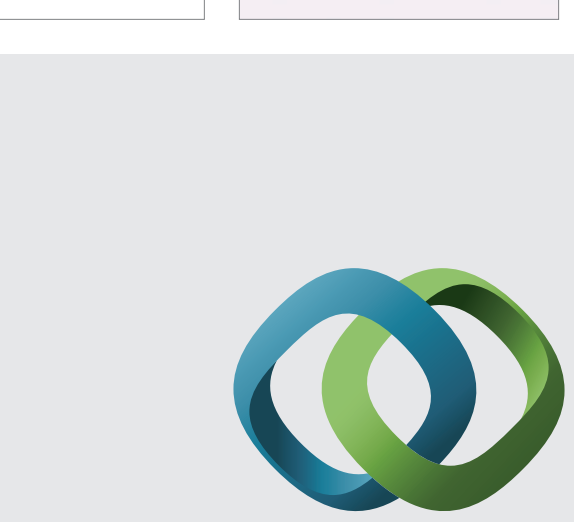

\section{Hindawi}

Submit your manuscripts at

http://www.hindawi.com
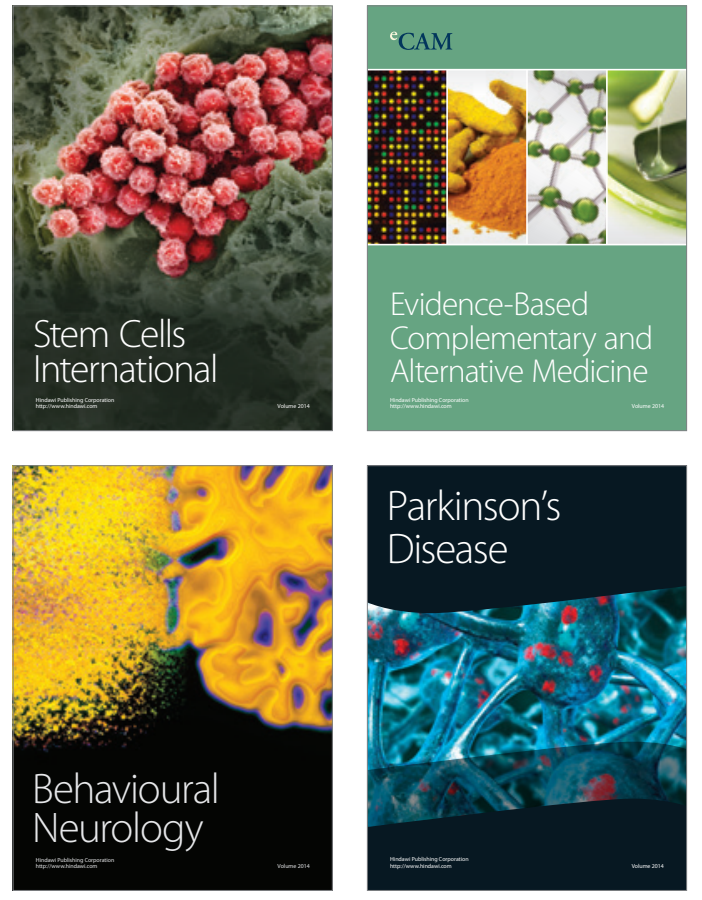
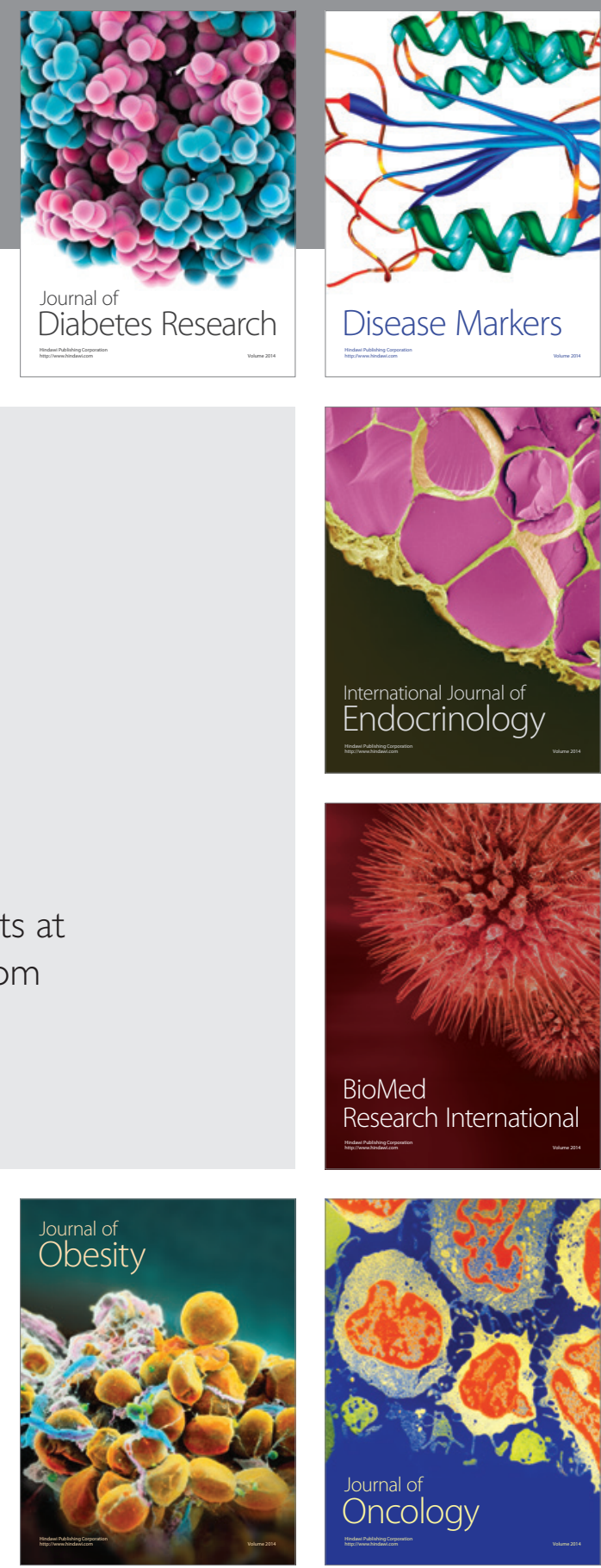

Disease Markers
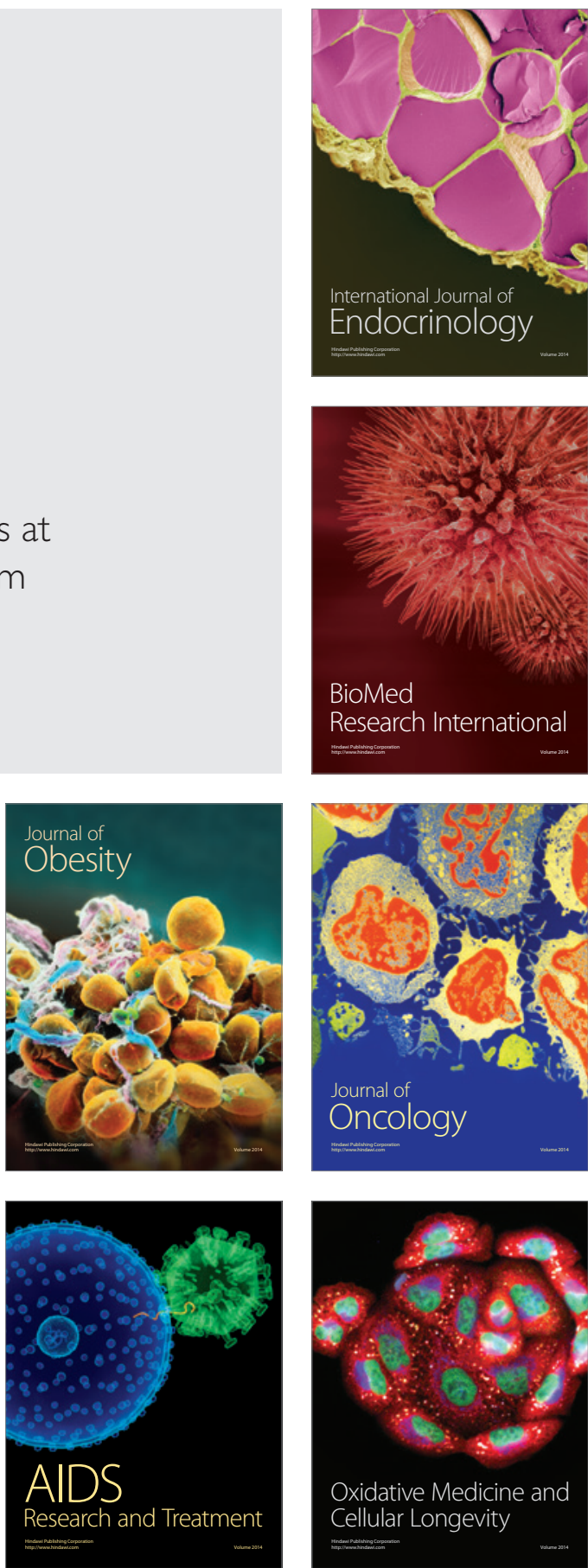